\title{
Paradoxical reaction to the treatment of tuberculosis uncovering previously silent meningeal disease
}

\author{
Reação paradoxal ao tratamento da tuberculose revelando \\ doença meníngea previamente silenciosa
}

Walter A. Eyer-Silva1 ${ }^{1}$, Jorge Francisco C. Pintoํㅜ, Juçara Árabe ${ }^{1}$ and Carlos Alberto Morais-de-Sá1

\begin{abstract}
The development of paradoxical clinical worsening following initiation of tuberculosis treatment may complicate the clinical course of both HIV-infected and uninfected patients. We report a severe manifestation of the so called paradoxical reaction to the treatment of tuberculosis that unmasked previously silent meningeal disease in a 34-year-old HIV-infected male patient.
\end{abstract}

Key-words: AIDS. Antiretroviral therapy. Paradoxical reaction. Tuberculosis. Tuberculous meningitis.

Resumo O desenvolvimento de piora clínica paradoxal como resposta ao início do tratamento da tuberculose pode complicar a evolução de pacientes com e sem infecção pelo HIV. Apresentamos uma grave manifestação da chamada reação paradoxal ao tratamento da tuberculose, que revelou doença meníngea previamente silenciosa em um paciente HIV-positivo de 34 anos.

Palavras-chaves: AIDS. Meningite tuberculosa. Reação paradoxal. Terapia anti-retroviral. Tuberculose.

Concomitantly treating active tuberculosis (TB) and HIV infection is a challenging task. There is a great potential for adverse effects and clinically significant pharmacological interactions. The development of paradoxical clinical worsening on TB treatment may further complicate patient management. We report a life-threatening manifestation of paradoxical worsening following TB treatment initiation in an antiretroviral (AR)-experienced patient.

\section{CASE REPORT}

A 34-year-old HIV-infected male patient with previous experience to the HIV reverse transcriptase inhibitors zidovudine and didanosine, to the HIV protease inhibitor saquinavir and on Pneumocystis carinii prophylaxis developed an enlarging cervical mass associated with a 2-month history of fever, weigh loss and malaise. At that point laboratory evaluation showed mild anemia (hemoglobin $11,3 \mathrm{mg} / \mathrm{dL}$ ), $60 \mathrm{CD} 4$ cells $/ \mathrm{mm}^{3}$ and a plasma HIV viral load of 25,000 copies $/ \mathrm{mL}$ (all viral load measurements were performed using the nucleic acid sequence-based amplification assay). Chest X-ray was normal. He had never had an opportunistic disorder but was treated for pleural TB during early adulthood. Histopathology disclosed TB lymphadenitis and Mycobacterium tuberculosis grew from the node aspirate. Rifabutin (as an alternative rifamycin to be combined with a protease inhibitor) at a dose of
$150 \mathrm{mg} /$ day, isoniazid, pyridoxine and pyrazinamide were started and the AR regimen was changed to stavudine, lamivudine and indinavir. He significantly improved and remained well until ten weeks later when recrudescence of fever and severe headache developed. Signs of meningeal irritation were absent, as were cognitive, behavioral or focal neurologic abnormalities. Computed tomography of the brain was normal. Cerebrospinal fluid (CSF) studies revealed marked pleocytosis $\left(220\right.$ cells $/ \mathrm{mm}^{3}, 71 \%$ polymorphonuclear, $29 \%$ mononuclear cells), glucose $52 \mathrm{mg} / \mathrm{dL}$ and elevated protein $(156 \mathrm{mg} / \mathrm{dL})$ and were negative for acid-fast bacilli, mycobacterial cultures, other infectious agents and neoplastic cells. Ophthalmologic examination disclosed TB choroidal nodules (previous evaluations had been normal). A presumptive diagnosis of TB meningitis was made and the clinical picture was

\footnotetext{
1. Department of Clinical Immunology do Hospital Universitário Gaffrée e Guinle da Universidade do Rio de Janeiro, Rio de Janeiro, RJ, Brazil. Presented in part, in poster form, at the XIII International Conference on AIDS, Durban, South Africa, 2000.

Address to: Dr. Walter A. Eyer-Silva. Hospital Universitário Gaffrée e Guinle. R. Mariz e Barros 775, 20270-004 Rio de Janeiro, RJ, Brazil.

Fax: $55212569-3025$

e-mail:walter-eyer@unirio.br

Recebido para publicação em 19/2/2001.
} 
considered consistent with a paradoxical response to therapy initiation. Prednisone and ethambutol were added to the above drugs. Headache slowly improved over the ensuing several weeks and the steroid was tapered until withdrawal 4 months later when CSF studies were entirely normal. He completed 14 months of TB therapy asymptomatic, with normal hemoglobin and resolution of the choroidal nodules. Shortly before completion of therapy the CD4 cell count was $170 / \mathrm{mm}^{3}$ and the plasma viral load 17,000 copies $/ \mathrm{mL}$. Nine months later the CD4 count was $310 / \mathrm{mm}^{3}$ and the viral load 19,000 copies/mL.

\section{DISCUSSION}

The paradoxical response to the TB treatment in our patient was of particular interest due to its life-threatening presentation, unmasking previously silent meningeal disease. Paradoxical worsening can occur in both HIVuninfected 1101315 and infected ${ }^{2} 4581112$ patients starting TB therapy and is generally attributed to a reconstituting host delayed hypersensitivity response with increased exposure to mycobacterial antigens under bactericidal therapy. Recrudescence of fever, enlarging adenopathies, worsening pulmonary infiltrates, pleural effusion, ascites, new or enlarging parenchymal central nervous system lesions and superior vena cava syndrome have all been reported ${ }^{1245810-1315}$. We are unaware of previous reports of paradoxical responses uncovering meningeal disease in HIV-infected patients.

Such paradoxical worsening syndromes pose a diagnostic challenge because the apparent clinical deterioration may raise the suspicion of drug-resistant $\mathrm{TB}$, noncompliance to the prescribed regimen or concomitant disorders unrelated to TB. These patients generally need no alteration in their drug regimen. At times, short-term steroid administration may be considered and was of great value in our patient.

Paradoxical worsening is by no means a recently observed complication of TB therapy initiation. In 1955 Choremis et $a^{\beta}$ reported that children starting TB therapy occasionally developed exacerbation of fever and X-ray findings. This phenomenon had been less frequently observed among children treated with streptomycin alone but markedly increased in frequency when combination therapy with streptomycin and isoniazid became standard of care. They acknowledged that the explanation for such a worsening was not easy but hypothesized that it might be related to marked bacteriolysis and liberation of tuberculin in large amounts.

In HIV-infected patients the syndrome of paradoxical worsening on TB treatment is not uncommon among those starting AR therapy and may well be considered a manifestation of the so called immune reconstitution syndrome. Narita et al $^{12}$ reported that a paradoxical reaction to TB treatment initiation occurred in 12 (36\%) of 33 HIV-infected patients concomitantly initiating both therapies, in $2(7 \%)$ of $28 \mathrm{HIV}$-infected patients treated for TB before the advent of AR therapy and in 1 (2\%) of 55 HIV-uninfected patients starting anti-TB regimens ${ }^{12}$. Also, HIV-infected patients initiating both therapies are more prone to develop transient chest radiographic worsening than HIV-uninfected and HIV-infected patients not on AR therapy ${ }^{4}$. Enhancing host immunity following initiation of AR therapy or its intensification with a protease inhibitor has also been implicated in the emergence of cytomegalovirus retinitis ${ }^{6}$, Mycobacterium avium complex lymphadenitis ${ }^{14}$, development of zoster rash $^{9}$, rapid worsening of Kaposi's sarcoma lesions ${ }^{7}$ and development of multiple cerebral lesions compatible with progressive multifocal leukoencephalopathy in AIDS patients ${ }^{7}$.

\section{REFERENCES}

1. Afghani B, Lieberman JM. Paradoxical enlargement or development of intracranial tuberculomas during therapy: case report and review. Clinical Infectious Diseases 19:1092-1099, 1994.

2. Chien JW, Johnson JL. Paradoxical reactions in HIV and pulmonary TB. Chest 114:933-936, 1998.

3. Choremis CB, Padiatellis C, Zoumboulakis D, Yannakos D. Transitory exacerbation of fever and roentgenographic findings during treatment of tuberculosis in children. American Review of Tuberculosis 72:527-536, 1955.

4. Fishman JE, Saraf-Lavi E, Narita M, Hollender ES, Ramsinghani R, Ashkin D. Pulmonary tuberculosis in AIDS patients: transient chest radiographic worsening after initiation of antiretroviral therapy. American Journal of Roentgenology 174:43-49, 2000.

5. Hill AR, Mateo F, Hudak A. Transient exacerbation of tuberculous lymphadenitis during chemotherapy in patients with AIDS. Clinical Infectious Diseases 19:774-776, 1994.

6. Jacobson MA, Zegans MZ, Pavan PR, O'Donnell JJ, Sattler F, Rao N, Owens S, Pollard R. Cytomegalovirus retinitis after initiation of highly active antiretroviral therapy. The Lancet 349:1443-1445, 1997.

7. Ledergerber B, Egger M, Erard V, Weber R, Hirschel B, Furrer H, Battegay M, Vernazza P, Bernasconi E, Opravil M, Kaufmann D, Sudre P, Francioli P, Telenti A, Swiss HIV Cohort Study. AIDSrelated opportunistic illnesses occurring after initiation of potent antiretroviral therapy. The Swiss HIV Cohort Study. Journal of the American Medical Association 282:2220-2226, 1999.

8. Lesprit P, Zagdanski AM, de la Blanchardiere A, Rouveau M, Decazes JM, Frija J, Lagrange P, Modai J, Molina JM. Cerebral tuberculosis in patients with the acquired immunodeficiency syndrome (AIDS). Report of 6 cases and review. Medicine 76:423-431, 1997.

9. Martinez E, Gatell J, Moran Y, Aznar E, Buira E, Guelar A, Mallolas $J$, Soriano E. High incidence of herpes zoster in patients with AIDS soon after therapy with protease inhibitors. Clinical Infectious Diseases 27:1510-1513, 1998.

10. Matthay RA, Neff TA, Iseman MD. Tuberculous pleural effusions developing during chemotherapy for pulmonary tuberculosis. American Review of Respiratory Diseases 109:469-472, 1974. 
11. Minguez C, Roca B, Gonzales-Mino C, Simon E. Superior vena cava syndrome during the treatment of pulmonary tuberculosis in an HIV-infected patient. Journal of Infection 40:187-189, 2000.

12. Narita M, Ashkin D, Hollender E, Pitchenik AE. Paradoxical worsening of tuberculosis following antiretroviral therapy in patients with AIDS. American Journal of Respiratory and Critical Care Medicine 158:157-161, 1998.

13. Onwubalili JK, Scott GM, Smith H. Acute respiratory distress related to chemotherapy of advanced pulmonary tuberculosis: a study of two cases and review of the literature. Quaterly Journal of Medicine 59:599-610, 1986.

14. Race EM, Adelson-Mitty J, Kriegel GR, Barlam TF, Reimann KA, Letvin NL, Japour AL. Focal mycobacterial lymphadenitis following initiation of protease-inhibitor therapy in patients with advanced HIV disease. The Lancet 351:252-255, 1998.

15. Rao GP, Nadh BR, Hemaratnan A, Srinivas TV, Reddy PK. Paradoxical progression of tuberculous lesions during chemotherapy of central nervous system tuberculosis. Journal of Neurosurgery 83:359-362, 1995. 